\title{
Predictability of Stock Returns using Financial Statement Information: Evidence on Semi-strong Efficiency of Emerging Greek Stock Market
}

\author{
Christos Alexakis $^{(a)}$ Theophano Patra ${ }^{(b)}$ Sunil Poshakwale ${ }^{(\mathrm{c})^{*}}$
}

(a) University of Piraeus, Department of Economics, Greece

(b) The American College of Greece, Department of Accounting and Finance, Greece

(c) School of Management, Cranfield University, England, MK43 0AL

Tel: +44 (0) 1234 754404, Fax: +44 (0) 1234752554

Email:sunil.poshakwale@cranfield.ac.uk

\begin{abstract}
The paper examines the predictability of stock returns in the Athens stock exchange during 1993-2006 by using accounting information. Using panel data analysis, the paper concludes that the selected set of financial ratios contain significant information for predicting the cross-section of stock returns. Results indicate that portfolios selected on the basis of financial ratios produce higher than average returns, suggesting that the emerging Greek market does not fully incorporate accounting information into stock prices and hence it is not semi-strong efficient.
\end{abstract}

*corresponding author 


\section{Financial Statement Ratios and Predictability of Stock Returns: Evidence from the Emerging Greek Market}

\section{Introduction}

The semi-strong form of the Efficient Market Hypothesis (EMH) requires that stock prices should fully reflect all publicly available information implying that investment strategies based on fundamental information e.g. financial ratios or economic indicators should not be able to offer abnormal returns, under a risk neutrality assumption $^{1}$ (Fama, 1991). There are several studies that have documented the predictive value of information available in financial statements in the US equity market. For instance, Ou and Penman (1989) develop a single summary measure that is capable of providing one-year-ahead earnings forecasts. Further evidence is provided by Holthausen and Larcker (1992), who find that financial ratio analysis is useful in predicting stock returns. Whilst Holthausen and Larcker (1992) utilise a large number of financial ratios in testing predictability of stock returns, Lev and Thiagarajan (1993) use only twelve financial ratios and demonstrate that the ratios very well correlate with returns after controlling for earnings innovations, firm size and macroeconomic conditions. Amongst other studies, Frankel and Lee (1998) enquire the usefulness of analyst-based valuation model in predicting cross-section of stock returns whilst Abarbanell and Bushee (1998) examine how fundamental signals generated by the financial statement data provide information for predicting future earnings changes in the US stocks. Using the same context, Nissim and Penman (2001) provide rigorous evidence on the utility of accounting ratios in projecting future streams of abnormal earnings. Similarly, Lewellen (2004) also reports evidence

\footnotetext{
${ }^{1}$ Under risk aversion one should account for a risk variable in the model tested, since variables found to be significant in predicting stock returns but also are correlated with risk, lose their significance when the model is adjusted for risk.
} 
that financial ratios have strong forecasting power on stock returns calculated during 1963-2000 period.

The literature that has used data from markets other than the US has also been growing. Cheung, Chung and Kim (1997) use a sample of Hong-Kong firms and examine the relative and incremental usefulness of book-to-price and earnings-toprice ratios for predicting stock returns. Martinez (1999) examines the association between financial ratios and stock returns for fifty industrial firms traded in the French stock market and confirms that financial statement information helps in predicting stock returns. In another study, Canbas, Duzakin, and Kilic (2002) indicate that financial data is useful in improving the quality of fundamental analysis for stock valuation in the Turkish stock exchange. In addition, Abekah (2005) investigates the emerging Ghana stock market and provides evidence on the predictability of stock returns using fundamental accounting variables.

The main objective of this paper is to examine predictability of the crosssection of stock returns in the Athens Stock Exchange (ASE) using accounting information. Specifically, the paper employs panel data analysis to investigate the relationship between stock returns and selected financial ratios for forty-seven firms traded in the ASE over the period 1993-2006. Further, the paper examines whether winner portfolios formed on the basis of previously determined financial ratios produce excess returns. Any evidence of abnormal returns on winner portfolios would provide evidence against the semi-strong efficient market hypothesis which requires that stock prices should fully incorporate publicly available information such as those contained in the financial statements.

There is relatively much less work on return predictability and performance of investment strategies using fundamental information in the Greek market. As far as 
we are aware, there is no previous study that has tested the semi-strong form of efficient market hypothesis using publicly available accounting data in the Athens Stock Exchange. However, there are a number of studies that have tested the weak form of the efficient market hypothesis. For example, Antoniou et al (2004) investigate availability of contrarian profits by testing the market overreaction hypothesis by using data from the ASE. Further, Galariotis (2004) investigates profitability of short-term contrarian profits and their sources. He uses Jegadeesh and Titman (1995) methodology but annually rebalances size-sorted sub-samples and finds evidence of short-run contrarian profits in the ASE. His findings suggest that though both underreaction to common factors and overreaction to the firm-specific return component appear to contribute to profits, the contribution of overreaction is much larger than that of underreaction. Theriou et al (2005) tests the applicability of the CAPM as well as firm specific factors. They employ Fama and French (1992) model using data from July 1993 to June 2001 and report that beta is not able to explain returns in the ASE. Patra and Poshakwale (2008) provide evidence on shortrun and long-run relationship amongst the main stock indexes in the ASE and find that changes in the banking sector index could be used in predicting changes in most other indexes confirming that the ASE is not weak form efficient.

Thus the literature survey suggests that whilst predictive power of accounting data has been extensively researched for developed markets such as the US, evidence on the emerging markets in general and the emerging Greek stock market in particular is scarce. This paper fills the gap in the existing literature by examining the predictability of stock returns based on accounting information in the emerging Greek stock market. The study is a first to use publicly available accounting information in testing the semi-strong efficient market hypothesis in the emerging Greek stock 
market. Using panel data analysis on data for 47 non-financial firms over for 19932006, the paper finds that the selected financial ratios contain significant information useful for predicting the cross-section of stock returns. Further findings suggest that winner portfolios formed on the basis of past financial ratios, produce higher than average returns thus violating the semi-strong efficient market hypothesis in the emerging Greek stock market.

The rest of the paper is organized as follows. Section 2 describes the data and the methodology. Section 3 reports the empirical results whilst Section 4 concludes.

\section{Data and methodology}

\subsection{Data description}

The data used in the present study comprise annual stock prices and financial ratios for a sample of forty-seven Greek firms listed on the ASE for the period 1993 to 2006. Data on all 47 firms were available only from 1993 and therefore we were constrained in selecting the sample period. All selected firms have been continuously trading during the sample period and are representative of the Greek market. Financial institutions and banks have been excluded from the sample because of differences in accounting practices and types of financial ratios used, compared to industrial firms. ${ }^{2}$ In Greece, the fiscal year ends in December every year and therefore to ensure that annual accounting information is publicly available as defined by the Efficient Market Hypothesis; June has been selected as the observation month ${ }^{3}$. The six month lag after the fiscal year-end allows for any possible delays in publication of financial statements by the Greek firms. Finally, the data used in this study were obtained from the ASE database from 1993-2006, which includes several "bull" and "bear" periods.

\footnotetext{
2 Cross sectional asset pricing studies typically exclude financial firms because of their high leverage and relatively greater industry regulations (see for example Fama and French (1992) among others).

${ }^{3}$ Annual financial data (December 31) of the Greek listed firms are reported by the end of March every year and the General Assemblies in which financial data are approved take place before the end of June and there is no evidence that financial data before and after the General Assembly differs.
} 
We select ten financial ratios as shown in Table 1 . The selection of ratios was based on the consideration these key ratios are commonly used by financial analysts in determining profitability, asset utilization, liquidity, and capital structure, and which capture the performance of a firm. Further, previous literature has also identified that these ratios are significant in predicting stock market returns in the cross-sectional setting (inter alia Martinez, 1999).

\subsection{Methodology}

The study uses panel data analysis that has several advantages. ${ }^{4}$ First, by combining the time series and cross sectional dimensions, panel data sets provide greater information, more variability, less collinearity among variables, more degrees of freedom and more analytical efficiency. Second, panel data can identify and measure effects that are not detectable in pure cross-section or pure time series analysis. Third, by studying repeated cross-section observations, panel data offers insights into the dynamics of change.

We consider the following dynamic panel data regression model:

$R_{i t}=\delta R_{i, t-1}+\beta \mathrm{X}_{i t}+u_{i t} \quad \mathrm{i}=1, \ldots, 47 \quad \mathrm{t}=1, \ldots, 12$

$u_{i t}=\alpha_{i}+\varepsilon_{i t}$

where firms are indicated by $\mathrm{i}$ and time by t. $R_{i t}$ is the $\log$ return for firm $i$ in year $t$, calculated as the difference of logarithmic prices between periods $t$ and $t-1$, i.e. $R_{t}=$ $\ln \left(\mathrm{P}_{\mathrm{t}}\right)-\ln \left(\mathrm{P}_{\mathrm{t}-1}\right) . \mathrm{X}_{i t}$ is the vector of explanatory variables, and $u_{i t}$ is the error term where $\alpha_{i}$ and $\varepsilon_{i t}$ are assumed to be mutually uncorrelated with zero mean and constant variance over time.

\footnotetext{
${ }^{4}$ See Baltagi (1996). However, Panel data is not without possible drawbacks. Problems that originate from cross-section and time series data such as heteroskedasticity and autocorrelation can also affect the panel data analysis (Gujarati, 2003).
} 
The presence of a lagged dependent variable among the regressors and the potential endogeneity of the explanatory variables render both fixed-effects and random- effects estimators inconsistent. Specifically, Nickell (1981) has shown that fixed-effect estimator is biased (for large $\mathrm{N}$ and small $\mathrm{T}$ ) because within transformation induces a correlation of order $1 / \mathrm{T}$ between the lagged dependent variable and the error. Further, the possible endogeneity of the included variables may arise because of the bidirectional causality between stock returns and certain explanatory variables. This implies that the error term in equation (2) is correlated with the endogenous regressors, and thus standard estimation procedures lead to seriously biased coefficients.

The regression equation is estimated by using the Generalised Method of Moments (GMM) specification proposed by Arellano and Bond (1991) that controls for the endogeneity of the explanatory variables and produces consistent estimators (Hansen and Singleton 1982). Specifically, the dynamic equation is first differenced to eliminate the individual effects and then it is estimated by instrumental variables using as instruments lagged values for the dependent and independent variables. Since the number of instruments is greater than the number of parameters, the estimated equation is overidentified. The validity of the instrument set is tested by using the Sargan (1964) test for overidentifying restrictions.

Before estimating equation (2) we examine the stationarity properties of the data series. A number of different panel unit root tests have been proposed by Maddala and Wu (1999), Choi (2001), Levin, Lin and Chu (2002), and Im, Pesaran and Shin (2003). All previous tests evaluate the null hypothesis of unit roots while the Hadri (2000) test examines the null hypothesis that all of series in the panel are stationary. We therefore use both Hadri (2000) and Im, Pesaran and Shin (2003) tests. 


\section{Empirical Results}

\subsection{Unit root tests}

Table 2 reports the results of panel unit root tests proposed by Hadri (2000) and Im, Pesaran and Shin (2003). For the level series, all variables except PER and PBV are non stationary in the panel. However, for the first differenced series, there is no statistical evidence of presence of a unit root.

\subsection{Panel estimation}

Empirical results of the panel data analysis are given in Table 3 where estimates of the model for each of the cross-sections are presented for three sub-periods i.e., 19932003, 1993-2004, and 1993-2005. The division of full sample period into three subperiods is based on the bull and bear periods that were observed in the Athens stock exchange. The findings reveal that the estimated coefficients of NPM, ROA and DA are not statistically significant in each of the three periods reported and were thus eliminated. ${ }^{5}$ However, consistent with the literature, liquidity ratios (asset turnover, current ratio) and profitability ratios (operating profit margin, return on equity) are significant and have a positive relationship with stock returns. The estimated sign for the price/earning ratio is negative indicating that companies with higher $\mathrm{P} / \mathrm{E}$ ratios (growth stocks) appear to have lower estimated returns compared to companies with low $\mathrm{P} / \mathrm{E}$ ratios (value stocks). Results confirm the expected negative association of between leverage (debt/equity ratio) and price to book ratio with the stock returns. We also test the validity of the instrument set used in the panel data equation using the Sargan test. The test results do not reject the null hypothesis that the over-identifying restrictions are valid.

\footnotetext{
5 The elimination of these variables has been done in stages. In particular, the variable that was first eliminated was the one with the smallest absolute t-statistic. Then we re-estimated the model and selected next variable for elimination on the basis of the lowest $t$-statistic.
} 


\subsection{Investment Strategies}

Next, the estimated parameters of equation (2) are used in formation of winner and loser portfolios for 2004, 2005, and 2006. Portfolios are constructed as follows. First, the estimated coefficients of the selected model from 1993-2003 are multiplied by the regressors for cross-section 2004 to estimate the 2004 returns. Next, the stocks are ranked according to their estimated returns and portfolios that consist of 10 stocks ( $20 \%$ of the sample) with the highest returns (winner portfolio) and 10 stocks with the lowest returns (loser portfolio) are constructed. The portfolios for 2005 and 2006 are constructed similarly using the data from 1993-2004 and 1993-2005. The empirical results of the investment strategy are presented in Table 4 and Figure 1.

The results displayed via Figure 1 show the performance of portfolios constructed from the 10 stocks with the highest returns and the lowest returns for years 2004, 2005, and 2006. The winner portfolios outperform the loser portfolios for all three years. Notably over 2004-2006 period, the winner portfolio has a cumulative positive return of $62.77 \%$ in contrast to cumulative negative return of $11.59 \%$ for the loser portfolio. This suggests that an investment strategy that buys winner portfolios and sells loser portfolios generates annual excess returns of $32.87 \%, 22.97 \%$, and $18.52 \%$. The results are consistent with the majority of empirical studies on developed capital markets (inter alia, see Lev and Thiagarajan (1993)).

\section{Conclusions}

This paper provides empirical evidence against the semi-strong efficient market hypothesis in the emerging Greek stock market under the assumption of risk neutrality and by using publicly available accounting information. Using data for 47 firms over 1993-2006 from the Athens Stock Exchange, the study analyses the panel data to investigate whether fundamental information as reflected in the financial ratios is able 
to explain stock returns. Further, the paper also examines the performance of investment strategy based on going long in winner portfolios and shorting loser portfolios that were formed on the basis of past financial ratios.

The empirical findings suggest that the selected financial ratios contain important information in predicting the cross-section of stock returns in the ASE. The investment strategy that involves buying winner portfolios and selling loser portfolios produces higher than average returns. The evidence presented in this paper suggests that the ASE does not fully incorporate publicly available accounting information into stock prices and hence violates the semi-strong efficient market hypothesis. 


\section{References}

Abarbanell A. and Bushee T. (1998), "Fundamental Analysis, Future Earnings and Stock Prices", Journal of Accounting Research, 2, 1-24.

Abekah, J. (2005), "Fundamental Variables and Stock Returns: Evidence from Ghana Stock Market", African Finance Journal, 7, 1, 18-36.

Antoniou, A., Galariotis, E. and Spyros, S. (2004), "Contrarian Profits and the Overreaction Hypothesis: the Case of the Athens Stock Exchange, European Financial Management, 11, 1, 71-98.

Arellano, M and Bond S. (1991), "Some Tests of Specification for Panel Data: Monte Karlo Evidence and an Application to Employment Equations», Review of Economic Studies, 58,277-297.

Baltagi B. (1996), Econometric Analysis of Panel Data, John Wiley and Sons, New York.

Canbas S., Duzakin H. and Kilic S. (2002), "Fundamental and Macroeconomic Information for Common Stock Valuation: The Turkish Case", Working Paper, Cukurova University.

Cheung J.K., Chung R. and Kim J.B. (1997), "The Profitability of Trading Strategies Based on Book Value and Earnings in Hong Kong: Market Inefficiency vs Risk Premia", Journal of International Financial Management and Accounting, 8, 204233.

Choi I. (2001), "Unit Root Tests for Panel Data", Journal of International Money and Finance, 20,249-272.

Fama, E. (1991), “Efficient Capital Markets II ”, Journal of Finance, 46,1575-1617.

Fama E. and French K. (1992), "Dividends Yields and Expected Stock Returns", Journal of Financial Economics, 5, 223-226.

Frankel R. and Lee C. (1988), "Accounting Valuation, Market Expectation, and Cross-Sectional Stock Returns", Journal of Accounting and Economics, 25, 283-319.

Galariotis E. C. (2004), "Sources of Contrarian Profits and Return Predictability in Emerging Markets", Applied Financial Economics, 14, (14), 1027-1034.

Gujarati D. (2003), Basic Econometrics, McGraw Hill, New York.

Hansen L. and Singleton K. (1982), "Generalized Instrumental Variables Estimation for Nonlinear Rational Expectations Models”, Econometrica, 63, 767-804.

Hadri K. (2000), "Testing for Stationarity in Heterogeneous Panel Data", Econometric Journal, 3,148-161. 
Holthausen W. and Larcker D. (1992), "The Prediction of Stock Returns using Financial Statement Information", Journal of Accounting and Economics, 15, 373411.

Im K.S.M.,Pesaran H. And Shin T. (2003), "Testing for Unit roots in Heterogeneous Panels", Journal of Econometrics, 115, 53-74.

Jegadeesh N. and Titman S. (1995), "Overreaction, Delayed Reaction, and Contrarian Profits", Review of Financial Studies, 8, 973-993.

Lev B. and Thiagarajan S. (1993), "Fundamental Information Analysis", Journal of Accounting Research, 31, 190-215.

Levin A., Lin C.F. and Chu C.S.J. (2002), "Unit Root Tests in Panel Data: Asymptotic and Finite-sample \{Properties", Journal of Econometrics, 108, 1-24.

Lewellen J. (2004), "Predicting Returns with Financial Ratios", Journal of Financial Economics, 74, 209-235.

Madala G.S. and Wu S.(1999), "A Comparative Study of Unit Root Tests with Panel Data and a New Simple Test",Oxford Bulletin of Economics and Statistics,61,631652.

Martinez I. (1999), "Fundamental and Macroeconomic Information for the Security Prices Valuation: The French Case", Managerial Finance, 12, 17-30.

Nickell S. (1981), "Biases in Dynamic Models with Fixed Effects", Econometrica, 49,1417-1426.

Nissim A. and Penman P. (2001), "Ratio Analysis and Equity Valuation: from Research to Practice”, Review of Accounting Studies, 6,109-154.

Ou J.A. and Penman S.H. (1989), "Financial Statement Analysis and the Prediction of Stock Returns", Journal of Accounting and Economics, 11, 295-330.

Patra T. and Poshakwale S. (2008), "Long-run and Short-run Relationships between the Main Stock Indexes: Evidence from the Athens Stock Exchange", Applied Financial Economics, 18, 1401-1410.

Sargan J.D. (1964), "Wages and Prices in the United Kingdom: a Study in Econometric Methodology". In Hart P.E, Mills G. and Whitaker J.K.(Eds). Econometric Analysis for National Economic Planning. Batterworths, London.

Theriou, N., Maditinos, D., Chadzoglou, P. and Anggelidis, V. (2005), "The CrossSection of Expected Stock Returns: an Empirical Study in the Athens Stock Exchange",Managerial Finance, 31, 12, 58-78. 
Table 1: Summary of Financial Ratios

\begin{tabular}{|c|c|c|}
\hline Ratio & Variable & Ratio Definition \\
\hline \multicolumn{3}{|l|}{ Profitability Ratios } \\
\hline Operating Profit Margin & OPM & Operating Income / Net Sales \\
\hline Net Profit Margin & NPM & Net Income / Net Sales \\
\hline Return on Assets & ROA & Net Income / Total Assets \\
\hline Return on Equity & ROE & Net Income / Shareholders' Equity \\
\hline Asset Utilization Ratios & & \\
\hline Asset Turnover & AT & Net Sales / Total Assets \\
\hline Debt Ratios & & \\
\hline Debt Ratio & DA & Total Debt / Total Assets \\
\hline Debt to Equity & $\mathrm{DE}$ & Total Debt / Shareholders Equity \\
\hline Investment Ratios & & \\
\hline P/E Ratio & PER & Stock Price / Earnings per Share \\
\hline Price to Book Ratio & PBV & Stock Price / Book Value per share \\
\hline Liquidity Ratios & & \\
\hline Current Ratio & CR & Current Assets / Current Liabilities \\
\hline
\end{tabular}


Table 2: Panel unit root tests

\begin{tabular}{|l|c|c|c|c|}
\hline \multicolumn{4}{|c}{ Level } & First Difference \\
\hline Variables & Hadri Z-test & $\begin{array}{c}\text { Im, Pesaran } \\
\text { and Shin W- } \\
\text { test }\end{array}$ & Hadri Z-test & $\begin{array}{c}\text { Im, Pesaran } \\
\text { and Shin W- } \\
\text { test }\end{array}$ \\
\hline R & $0.075^{*}$ & 7.681 & 0.417 & $10.985^{*}$ \\
OPM & $10.212^{*}$ & 0.289 & 1.804 & $7.491^{*}$ \\
NPM & $9.666^{* *}$ & -0.278 & 1.214 & $8.038^{*}$ \\
ROA & $7.196^{*}$ & -1.604 & 3.873 & $9.232^{* *}$ \\
ROE & $6.822^{*}$ & -1.059 & 3.061 & $8.078^{*}$ \\
AT & $9.756^{* *}$ & -0.218 & 5.327 & $9.891^{*}$ \\
DA & $10.507^{*}$ & -0.741 & 3.205 & $7.998^{* *}$ \\
DE & $4.393^{*}$ & -3.104 & -0.317 & $7.665^{*}$ \\
PER & 0.789 & $4.876^{*}$ & & \\
PBV & 0.589 & $5.316^{* *}$ & 6.662 & $9.161^{*}$ \\
CR & $8.351^{*}$ & -1.607 & 607 \\
\hline Notes: ** and * indicate rejections of the null hypothesis at 5\% and \\
$10 \%$ level of significance.
\end{tabular}


Table 3: Panel data estimation results

\begin{tabular}{|c|c|c|c|}
\hline \\
\hline Variables & 1993-2003 & 1993-2004 & $1993-2005$ \\
\hline OPM & $\begin{array}{c}0.007 * \\
(-4.4610\end{array}$ & $\begin{array}{c}0.006^{*} \\
(-3.138)\end{array}$ & $\begin{array}{l}0.005^{* *} \\
(-2.704)\end{array}$ \\
\hline NPM & $\begin{array}{c}1.098 \\
(-1.024)\end{array}$ & $\begin{array}{c}0.076 \\
(-0.909)\end{array}$ & $\begin{array}{c}0.045 \\
(1.256)\end{array}$ \\
\hline $\mathrm{ROA}$ & $\begin{array}{c}0.045 \\
(1.338) \\
\end{array}$ & $\begin{array}{c}0.017 \\
(1.255) \\
\end{array}$ & $\begin{array}{c}0.091 \\
(-1.038) \\
\end{array}$ \\
\hline ROE & $\begin{array}{l}0.027^{*} \\
(2.245)\end{array}$ & $\begin{array}{l}0.025^{*} \\
(2.231) \\
\end{array}$ & $\begin{array}{l}0.031^{*} \\
(3.851) \\
\end{array}$ \\
\hline AT & $\begin{array}{l}1.269^{* *} \\
(2.256)\end{array}$ & $\begin{array}{l}1.142^{*} \\
(-2.612)\end{array}$ & $\begin{array}{c}0.876^{*} \\
(2.786)\end{array}$ \\
\hline $\mathrm{DA}$ & $\begin{array}{c}0.623 \\
(0.231) \\
\end{array}$ & $\begin{array}{r}0.005 \\
(1.354) \\
\end{array}$ & $\begin{array}{c}0.275 \\
(1.620) \\
\end{array}$ \\
\hline $\mathrm{DE}$ & $\begin{array}{l}-0.002 * * \\
(3.329)\end{array}$ & $\begin{array}{c}-0.004 * * * \\
(-4.377) \\
\end{array}$ & $\begin{array}{l}-0.008^{* *} \\
(4.304)\end{array}$ \\
\hline PER & $\begin{array}{c}-0.003 * * \\
(8.132)\end{array}$ & $\begin{array}{l}-0.002^{* *} \\
(-6.525)\end{array}$ & $\begin{array}{l}-0.018^{*} \\
(7.256)\end{array}$ \\
\hline $\mathrm{PBV}$ & $\begin{array}{l}-0.117^{* *} \\
(12.641) \\
\end{array}$ & $\begin{array}{l}-0.106^{*} \\
(10.923) \\
\end{array}$ & $\begin{array}{l}-0.097 * * \\
(10.614) \\
\end{array}$ \\
\hline $\mathrm{CR}$ & $\begin{array}{c}0.142^{* * *} \\
(-5.966) \\
\end{array}$ & $\begin{array}{c}0.141 * * * \\
(5.864) \\
\end{array}$ & $\begin{array}{c}0.098^{* *} \\
(3.128) \\
\end{array}$ \\
\hline Sargan test (p-value) & 0.667 & 0.589 & 0.497 \\
\hline S.E. of regression & 0.437 & 0.369 & 0.128 \\
\hline $\begin{array}{r}\text { Notes: 1) Figures in parenthes } \\
\text { at } 1 \%, 5 \% \text { and } 10 \% 1 \\
\text { 2) Since first differenc } \\
\text { effects have been elir }\end{array}$ & $\begin{array}{l}\text { es. } * * *, * * \text { a } \\
\text { panel estims } \\
\text { timated equa }\end{array}$ & $\begin{array}{l}\text { nd } * \text { indicate } \\
\text { tion, firm an } \\
\text { tion. }\end{array}$ & significance \\
\hline
\end{tabular}


Table 4: Portfolio Summary Results

\begin{tabular}{lcccc}
\hline & $\mathbf{2 0 0 4}$ & $\mathbf{2 0 0 5}$ & $\mathbf{2 0 0 6}$ & Cumulative \\
\hline Annual Return & & & & \\
Loser Portfolio & -28.28 & 5.45 & 11.24 & -11.59 \\
Winner Portfolio & 4.59 & 28.42 & 29.76 & 62.77 \\
& & & & \\
Excess Returns & 32.87 & 22.97 & 18.52 & 74.36 \\
\hline
\end{tabular}

Figure 1: Excess Returns

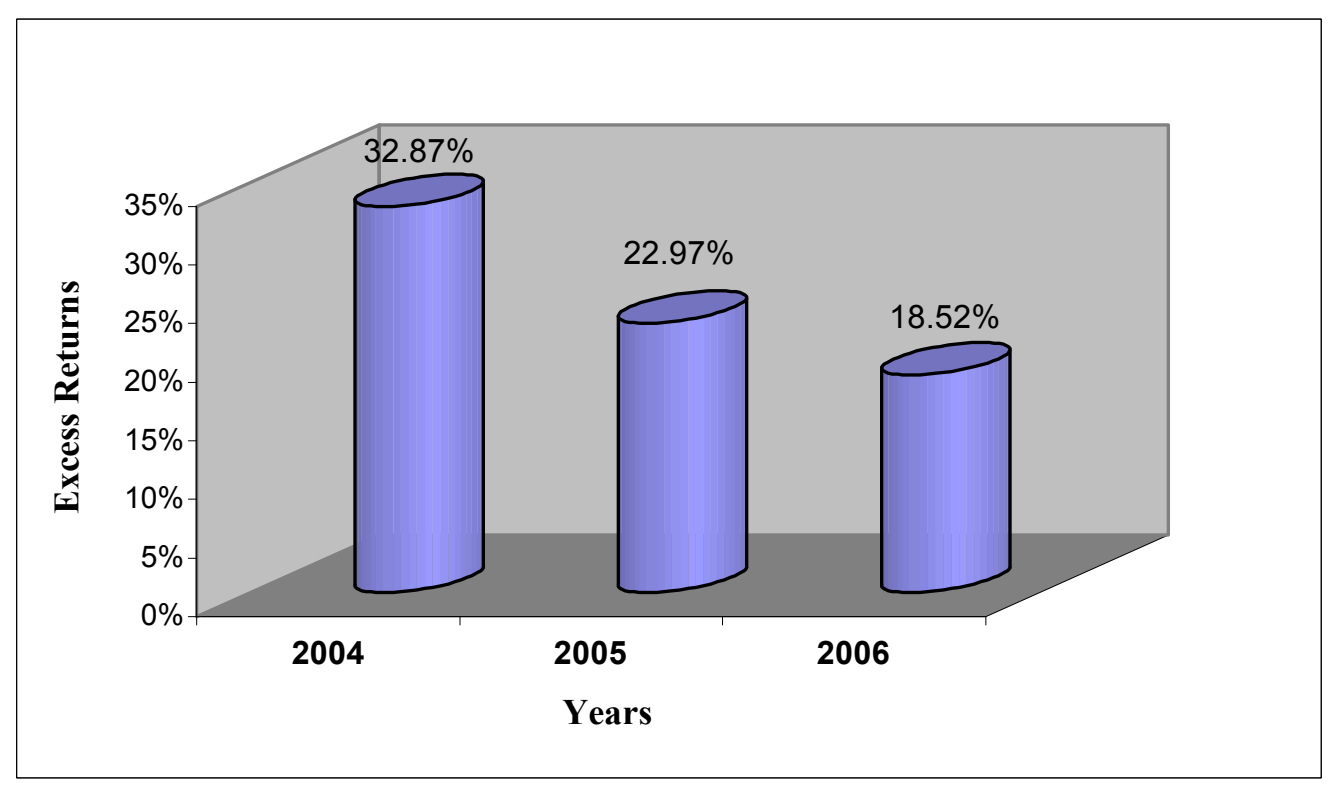

